\title{
AKTIVITAS INULINASE OLEH Pichia manshurica DAN FUSAN F4 PADA FERMENTASI BATCH DENGAN UMBI DAHLIA (Dahlia sp) SEBAGAI SUBSTRAT
}

\author{
Wijanarka $^{\left.1^{*}\right)}$, Endang Sutariningsih Soetarto ${ }^{2)}$, Kumala Dewi ${ }^{3)}$, dan Ari Indrianto ${ }^{4)}$ \\ ${ }^{1)}$ Lab. Mikrobiologi, FSM UNDIP; mahasiswa S3 Biologi UGM, Bulaksumur Jogyakarta 55281 \\ ${ }^{2)}$ Lab. Mikrobiologi, Fak. Biologi UGM, Bulaksumur Jogyakarta 55281 \\ ${ }^{3)}$ Lab. Fisiologi Tumbuhan, Fak. Biologi UGM, Bulaksumur Jogyakarta 55281 \\ ${ }^{4)}$ Lab. Bioteknologi, Fak. Biologi UGM, Bulaksumur Jogyakarta 55281 \\ ${ }^{*}$ Penulis korespondensi : wikasmara@yahoo.co.id.
}

\begin{abstract}
ACTIVITY OF INULINASE OF Pichia Manshuria AND FUSAN F4 ON BATCH FERMENTATION UDING DAHLIA TUBER (Dahlia sp) AS A SUBSTRATE. A dahlia tuber is one of the common inulin rich crops. Inulin is formed by units of fructans, which are polymers of Dfructose. Inulinases (EC 3.2.1.7) catalyze the hydrolysis of inulin, producing fructooligosaccharides (FOS), inulooligosaccharides (IOS), pulullan, acetone, butanol and sorbitol, therefore dahlia tubers are used as growth media. The inulin hydrolyzing activity has been reported from various microbial strains Pichia manshurica and Fusan F4 which is the result of fusion protoplast. The objective of this study was to determine the activity of inulinase Pichia manshurica and Fusan F4 on the substrate dahlia tubers. Fusan F4 to increase inulinase activity compared with Pichia manshurica and to investigate the kinetics of specific growth rate $(\mu)$ and time double $(g)$ from of Pichia manshurica and Fusan F4. The results showed that the exponential phase occurs at 0-12 hour without a lag phase. P. manshurica has a specific growth rate $(\mu)$ of $0.18 /$ hour with time double $(g) 3.90$ hours and the inulinase enzyme activity of $0.56 \mathrm{IU}$, while for Fusan F4 consecutive has a value $\mu$ of 0.20/hour, $g$ of 3.49 hours and the activity of 0.69 IU. The conclusion of this research is to improve Fusan F4 inulinase activity and the ability has to be better than the Pichia manshurica.
\end{abstract}

Keywords: dahlia tuber; Fusan F4; growth kinetics; inulinase; Pichia manshurica

\begin{abstract}
Abstrak
Umbi dahlia merupakan salah satu umbi yang mengandung inulin. Inulin merupakan polimer fruktan yang dapat dipecah oleh enzim inulinase (E.C. 3.2.1.7) menjadi fruktosa. Fruktosa merupakan bahan baku dasar untuk pembuatan FOS, IOS, pulullan, aseton dan sorbitol, oleh karena itu umbi dahlia digunakan sebagai media pertumbuhan. Enzim inulinase ini secara indigenous dimiliki oleh Pichia manshurica dan Fusan F4 yang merupakan hasil fusi protoplas.Tujuan penelitian ini adalah untuk mengetahui aktivitas inulinase Pichia manshurica dan Fusan F4 pada substrat umbi dahlia, Fusan F4 mampu meningkatkan aktivitas inulinase dibandingkan dengan Pichia manshurica serta untuk mengetahui kinetika kecepatan pertumbuhan specifik ( $\mu$ ) dan waktu generasi (g) Pichia manshurica dan Fusan F4. Hasil penelitian menunjukkan bahwa fase eksponensial terjadi pada jam ke-0 sampai jam ke-12 tanpa diikuti fase lag, Pichia manshurica mempunyai kecepatan pertumbuhan specific $(\mu)$ sebesar 0,18/jam dengan waktu generasi (g) 3,90 jam dan aktivitas enzim inulinase yang dihasilkan sebesar 0,56 IU, sedangkan untuk fusan F4 secara berturut-turut mempunyai nilai $\mu$ sebesar 0,20/jam, g sebesar 3,49 jam dan aktivitas sebesar 0,69 IU. Kesimpulan dari penelitian ini adalah Fusan F4 mampu meningkatkan aktivitas inulinase dan mempunyai kemampuan lebih baik dibanding dengan Pichia manshurica.
\end{abstract}

Kata kunci: umbi dahlia; Fusan F4; kinetika pertumbuhan; inulinase; Pichia manshurica 


\section{PENDAHULUAN}

Tanaman dahlia (Dahlia sp) merupakan tanaman yang tumbuh sebagai perdu setinggi $1,5 \mathrm{~m}$ atau lebih dengan membentuk rumpun umbi akar pada bagian dasar dari batangnya. Jaringan dalam umbi akar berfungsi sebagai tempat penyimpanan cadangan makanan. Bentuk umbi akar dahlia bervariasi mulai dari bulat kecil sampai besar, panjang sampai lonjong. Struktur umbi dahlia terdiri atas kulit umbi berwarna putih kekuning-kuningan sampai kecoklatan, daging umbi tebal baerwarna putih atau bening dan mempunyai mata tunas. Tanaman ini merupakan satu jenis tanaman hias potensial yang baik untuk dikembangkan secara komersial. Nilai komersial tanaman dahlia tidak hanya terletak pada bunganya tetapi juga pada umbinya. Umbi dahlia mengandung inulin sebesar 65,7\% (Rukmana, 2000)

Inulin adalah suatu senyawa polimer fruktan yang dapat dihidrolisis menjadi fruktosa, tidak memberi warna bila dalam larutan inulin ditambahkan yodium dan mudah larut dalam air panas (Mayes dkk., 1987). Inulin terdapat sebagai cadangan karbohidrat pada umbi sejumlah tanaman yang termasuk dalam familia Compositeae (Xiao dkk., 1988). Total persentase gula sebagai fruktosa dalam inulin bervariasi antara 75-98\%, tergantung pada kondisi penyimpanan setelah umbi tanaman di panen (Byun dan Nahm, 1978). Inulin merupakan polifruktan, yaitu polimer fruktosa rantai linier dengan ikatan $\beta$-21fruktofruktanosidik dengan satu rantai terminal glukosa di ujung, dengan panjang rantai polisakarida ini kurang lebih 25-35 unit fruktosa (Allais dkk., 1986). Inulin mempunyai banyak kegunaan terutama dibidang pangan dan kesehatan. Di bidang kesehatan, inulin antara lain berperan mencegah kanker usus besar dan penyakit jantung (Tungland, 2000).

Inulinase (E.C. 3.2.1.7) merupakan enzim hidrolase dan di golongkan sebagai enzim ektraseluler yang mampu menghidrolisis inulin menjadi fruktooligosakarida (FOS) dengan memotong satuan fruktosa dari inulin pada posisi terminal $\beta-2,1$ (Rouwenhorst dkk., 1990; Park dan Yun, 2001). Enzim ini dapat diisolasi dari tanaman yang mengandung inulin yaitu dari familia Compositae (Xiao dkk., 1988). Enzim inulinase juga dapat ditemukan dari golongan jamur Aspergillus sp, Penicillium sp, Chrysosporium sp, Khamir (yeast) Kluyveromyces sp, Candida sp, Debaromyces dan Saccharomyces sp dari golongan bakteri Arthrobacter sp, Flavobacterium sp dan Bacillus sp (Allais dkk., 1986 ; Xiao dkk., 1988). Aplikasi dari inulinase dapat digunakan untuk produksi inulouligosakarida (IOS), fruktouligosakarida (FOS), sorbitol, pullulan, ethanol, aseton dan butanol.

Pichia manshurica merupakan salah satu khamir indigenous yang bersifat inulinolitik yang secara alami ditemukan di umbi dahlia (Lunggani dkk., 2009). Khamir ini mempunyai kemampuan dalam menghasilkan enzim inulinase sebesar 0,683 IU. Neagu dan Bahrim (2011) melaporkan khamir
Yarrowia lipolytica mampu menghasilkan aktivitas inulinase sekitar 22,5-62,85 IU dan kapang Rizoctonia solani sebesar 1,79 IU. Karakteristik khamir Pichia manshurica adalah sel berbentuk bulat telur, bisa tunggal dan berpasangan dengan panjang 2-7 $\mu \mathrm{m}$ dan lebar 2-5 $\mu \mathrm{m}$. Pertunasannya multipolar, dapat membentuk miselium palsu dan sejati. Koloni berwarna agak krem, permukaan halus, bagian tengah koloni menggunung, dan menghasilkan spora seksual berbentuk bulat. Pichia manshurica mampu tumbuh pada suhu $37^{\circ} \mathrm{C}$, sedangkan Fusan F4 merupakan hasil fusi protoplas secara intraspecifik Pichia manshurica.

Penelitian Wijanarka dkk. (2005) telah menemukan fusan baru yang merupakan fusi antara khamir Kluveromyces marxianus dan Torulospora pretoriensis isolat lokal. Fusan baru tersebut telah terbukti mampu meningkatkan aktivitas inulinase dari 0,1045 IU/ml (Torulospora pretoriensis isolat local) menjadi 0,1298 IU/ml, sedangkan bila dibanding dengan induk Kluveromyces marxianus sedikit lebih rendah $(0,1492 \mathrm{IU} / \mathrm{ml})$. Aktivitas yang rendah ini dikarenakan, fusan baru tersebut belum ditumbuhkan pada kondisi lingkungan yang optimum dan enzim yang digunakan dalam bentuk crude enzim.

Sejauh ini di Indonesia belum ada penelitian Pichia manshurica dan Fusan F4 terutama yang mengkaji tentang produksi inulinase dan kinetika pertumbuhan. Kinetika pertumbuhan secara dinamik dapat digunakan untuk meramalkan produksi biomasa dalam suatu proses. Dari fakta tersebut di atas, maka perlu dilakukan penelitian potensi inulin umbi tanaman dahlia sebagai media pertumbuhan dan produksi inulinase oleh Pichia manshurica dan Fusan F4.

Menurut Mangunwidjaja dan Ani (1994), pertumbuhan mikrobia dapat dipandang sebagai suatu rangkaian reaksi kimia yang mengendalikan sintesis biomasa yang diperoleh pada akhir kultur. Sedangkan kinetika pertumbuhan merupakan teknik evaluasi suatu populasi mikroba baik secara kuantitaif maupun kualitatif dapat digunakan untuk memantau dan mengkaji fenomena pertumbuhan

Penelitian ini bertujuan untuk mengetahui aktivitas inulinase Pichia manshurica dan Fusan F4 pada fermentasi batch dengan umbi dahlia sebagai substrat, Fusan F4 mampu meningkatkan aktivitas inulinase dibandingkan dengan Pichia manshurica serta untuk mengetahui kinetika kecepatan pertumbuhan specifik ( $\mu$ ) dan waktu generasi (g) Pichia manshurica dan Fusan F4.

\section{METODE PENELITIAN}

\section{Mikroorganisme dan Kultur Medium}

Kultur murni khamir Pichia manshurica dan Fusan F4 diperoleh dari hasil koleksi Laboratorium Mikrobiologi FMIPA Universitas Diponegoro. Media untuk pemeliharaan kultur dan produksi enzim (g/L): inulin (30); $\mathrm{NH}_{4} \mathrm{NO}_{3}$ (2,3); $\left(\mathrm{NH}_{4}\right)_{2} \mathrm{HPO}_{4} \quad(3,7)$; $\mathrm{K}_{2} \mathrm{HPO}_{4}(1) ; \mathrm{MgSO}_{4} \cdot 7 \mathrm{H}_{2} \mathrm{O}(0,5)$; yeast ekstrak $(1,5)$ dan pH 5,0 (Erthan dkk., 2003). 


\section{Ekstraksi Inulin dari Umbi Dahlia}

Umbi dahlia dipilih dan dikupas kemudian dicuci dengan air sampai bersih. Umbi dipotong kecil dan tipis sehingga mempunyai ketebalan $\pm 0,5 \mathrm{~cm}$ dan dikeringkan dengan sinar matahari selama 3-5 hari. Umbi yang telah kering (kadar air 11,94\%) dihaluskan dengan menggunakan blender sampai menjadi tepung. Tepung ditimbang sebanyak $3 \mathrm{~g}$, disuspensikan ke dalam $100 \mathrm{ml}$ aquades dan dipanaskan hingga mendidih selama 20 menit untuk melarutkan inulin. Selanjutnya dilakukan penyaringan dan filtrat yang didapat diasumsikan berisi inulin yang akan digunakan sebagai sumber karbon khamir untuk produksi enzim (Pessoa dan Vitolo, 1999; Erthan dkk.,2003; Wijanarka dkk., 2006).

\section{Medium untuk Pertumbuhan dan Produksi Enzim Inulinase}

Komposisi medium produksi enzim inulinase sama persis dengan medium kultur. Selanjutnya medium tersebut disterilisasi dengan menggunakan autoklaf pada suhu $121^{\circ} \mathrm{C}$ selama 20 menit dengan tekanan 2 atm. Kemudian dilakukan inokulasi starter Pichia manshurica $10 \%\left(10^{7} \mathrm{sel} / \mathrm{ml}\right)$ pada erlenmeyer yang berisi $50 \mathrm{ml}$ medium untuk pertumbuhan dan produksi enzim serta digoyangkan dengan menggunakan alat shaker dengan kecepatan 120 rpm. Selanjutnya dilakukan pengamatan pertumbuhan dan produksi enzim setiap 6 jam sekali selama 48 jam.

\section{Pengukuran Aktivitas Inulinase}

Aktivitas inulinase ditentukan dengan metode 3,5-dinitrosalicylic acid (DNS) dengan menggunakan inulin sebagai substrat (Chaplin and Kennedy, 1994). Pengukuran absorbansi menggunakan spektrofotometer Optima (Tipe SP30 pada $\lambda=520 \mathrm{~nm}$ ). Satu unit aktivitas enzim adalah sejumlah enzim yang mampu membebaskan $1 \mu$ mol fruktosa inulin per menit. Penentuan aktivitas inulinase dapat ditentukan menurut rumus (Bonciu dkk., 2010: Park dan Yun, 2001) :
Aktivitas Enzim (IU) =

$$
\frac{(\text { AbsES - AbsE - AbsS). fruktosa }}{\text { BMf } t} \times \mathrm{P} \text { x } 1000
$$

dimana :

Abs ES = absorbansi enzim substrat;

Abs E = absorbansi enzim;

Abs ES = absorbansi enzim substrat;

Abs $\mathrm{S}=$ absorbansi substrat;

$\mathrm{BM} f=$ berat molekul fruktosa $(180,1 \mathrm{gr} / \mathrm{mol})$;

$\mathrm{P}=$ faktor pengenceran $(50 \mathrm{x})$;

$\mathrm{t}$ = waktu inkubasi selama 30 menit;

dengan persamaan regresi kurva fruktosa standar

$\mathrm{Y}_{\text {fruktosa }}=0.5398 \mathrm{X}_{\text {nilai OD }}$

\section{Pengukuran Kecepatan Pertumbuhan Specifik $(\mu)$ dan Waktu Generasi (g)}

Kecepatan pertumbuhan specifik didefinisikan sebagai perubahan populasi (X) terhadap waktu (t) (Okpokwaili dan Nweke, 2005). Kultur sampel diambil sebanyak $5 \mathrm{ml}$ dan dilakukan pengukuran pertumbuhan dengan menggunakan spektrofotometer pada panjang gelombang 520 nm. Kecepatan pertumbuhan specifik $(\mu)$ dan waktu generasi (g) ditentukan menurut rumus Dinoto (2006)

$$
\mu=\frac{\ln \mathrm{Xt}_{2}-\ln \mathrm{Xt}_{1}}{\mathrm{t}_{2}-\mathrm{t}_{1}}
$$

Waktu generasi (jam) : waktu yang diperlukan untuk membelah diri dari satu menjadi dua sel sempurna.

$$
\mathrm{g}=\frac{0,693}{\mu}
$$

dimana :

$\mu=$ kecepatan pertumbuhan specifik (/jam);

$\mathrm{g}=$ waktu generasi (jam);

$\mathrm{Xt}_{1}=$ nilai OD ke-1;

$\mathrm{Xt}_{2}=$ nilai OD ke-2;

$\mathrm{t}_{1}=$ waktu jam ke-1 awal fase log;

$\mathrm{t}_{2}=$ waktu jam ke-2 awal fase log

\section{HASIL DAN PEMBAHASAN \\ Pertumbuhan Pichia manshurica}

Khamir P. manshurica (Gambar 1 A) dan Fusan F4 (Gambar 1 B) ditumbuhkan pada medium pertumbuhan, dimana inulin umbi dahlia digunakan sebagai satu-satunya sumber karbon.

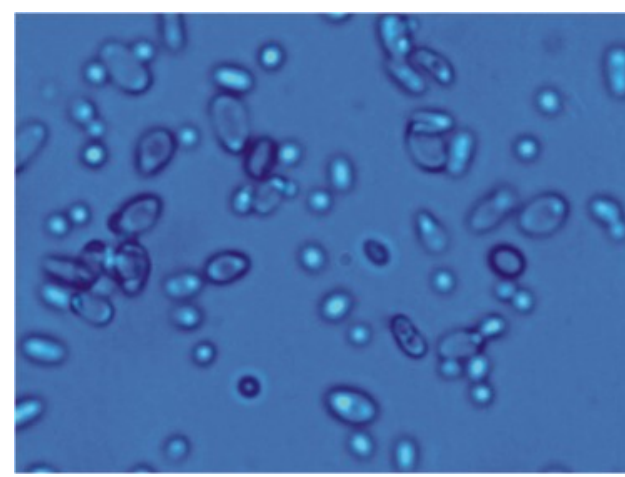

A

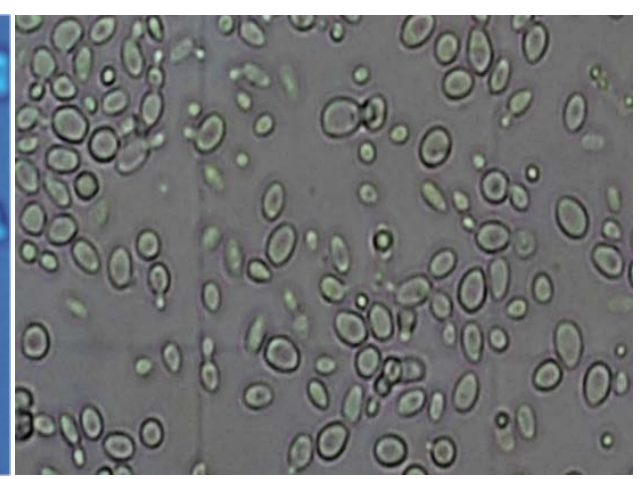

B

Gambar 1. A. Pichia manshurica ( perbesaran 400 x)

B. Fusan F4 ( perbesaran 400 x) 
Berdasarkan hasil analisis kandungan inulin di umbi dahlia sekitar sebesar 16,101 $\mathrm{mg} / \mathrm{ml}$. Sumber karbon inulin yang terkandung di umbi dahlia dapat di gunakan sebagai bioenergi dan biosintesis untuk proses pertumbuhan. Mahmoud dkk. (2011) melaporkan bahwa daun bawang kering juga mengandung inulin yang berfungsi sebagai sumber karbon serta dapat digunakan untuk produksi inulinase. Songpim dkk. (2011) dan Madigan dkk. (2009) melaporkan bahwa sumber karbon sangat penting untuk proses metabolisme, dengan adanya penambahan sumber nitrogen dan mineral akan meningkatkan aktivitas enzim atau biokatalisator, sehingga akan mempercepat proses regenerasi. Ditambahkan juga bahwa pertumbuhan mikroba ditandai dengan adanya kenaikan konsentrasi biomasa dan mensekresikan produk-produk metabolit.

Berdasarkan hasil penelitian, ternyata Pichia manshurica dan Fusan F4 mampu hidup dan memperbanyak diri dalam waktu yang singkat tanpa adanya fase lag. Hal ini dibuktikan dengan adanya kenaikan nilai absorbansi biomasa (X), dalam keadaan yang sama juga terjadi kenaikan produk metabolit (P) dan penurunan jumlah substrat (S). Laju pertumbuhan specifik $(\mu)$ sangat berkaitan sekali dengan fase log (eksponensial) dan tak boleh dipisahkan. Pada fase ini pertumbuhan akan mencapi titik maksimum, sehingga akan terjadi pertumbuhan secara logaritmik atau trophofase. Pada keadaan seperti ini, maka $\mu$ (laju pertumbuhan specifik) tetap, komposisi seluler yang tetap, namun komposisi kimiawi substrat (S) berubah. Hal ini dapat terjadi karena adanya proses pembentukan produk (P) yaitu enzim dan pengurangan penggunaan substrat. Pichia manshurica mempunyai kecepatan pertumbuhan specific $(\mu)$ sebesar $0,18 /$ jam dengan waktu generasi (g) 3,90 jam dan aktivitas enzim inulinase yang dihasilkan sebesar 0,56 IU, sedangkan untuk Fusan F4 secara berturut-turut mempunyai nilai kecepatan pertumbuhan specific $(\mu)$ sebesar 0,20/jam, waktu generasi (g) sebesar 3,49 jam dan aktivitas inulinase sebesar 0.69 IU. Berdasarkan nilai tersebut, maka Fusan F4 lebih baik dari pada Pichia manshurica. Kecepatan pertumbuhan ini mencerminkan bahwa Fusan F4 dan Pichia manshurica mempunyai kemampuan pertumbuhan bagus dan berkaitan langsung dengan fase eksponensial serta produk (enzim inulinase). Penambahan atau kenaikan biomasa (X) dan produk hasil metabolit (P) memiliki pola pertumbuhan yang sama. Menurut Mangunwidjaja dan Ani (1994), bahwa antara biomasa (X) dan produk metabolit (P) bersifat growth associated, yaitu pembentukan produk berasosiasi dengan pertumbuhan (Gambar 3 dan Gambar 4).

Berdasarkan penelitian yang telah dilakukan, ternyata fase log (eksponensial) dimulai pada jam ke-0 sampai jam ke-12 tanpa diikuti fase lag (adaptasi), selanjutnya setelah jam tersebut diikuti fase stasioner. Hal ini disebabkan adanya starter yang diberikan pada medium pertumbuhan tersebut. Adanya starter 10\% (v/v) ini mengakibatkan Pichia manshurica dan Fusan F4 langsung mengalami pertumbuhan log tanpa adaptasi dulu dengan lingkungan setempat. Hal ini di dukung dengan pendapat Alexander dan Jeffries (1990) yang menyatakan bahwa adanya starter di dalam media pertumbuhan dapat meniadakan fase lag dan pertumbuhan akan langsung memasuki fase eksponensial. Santopietro dkk. (1997) melaporkan bahwa kondisi starter yang ideal untuk fermentasi khamir berkisar $10 \%$.
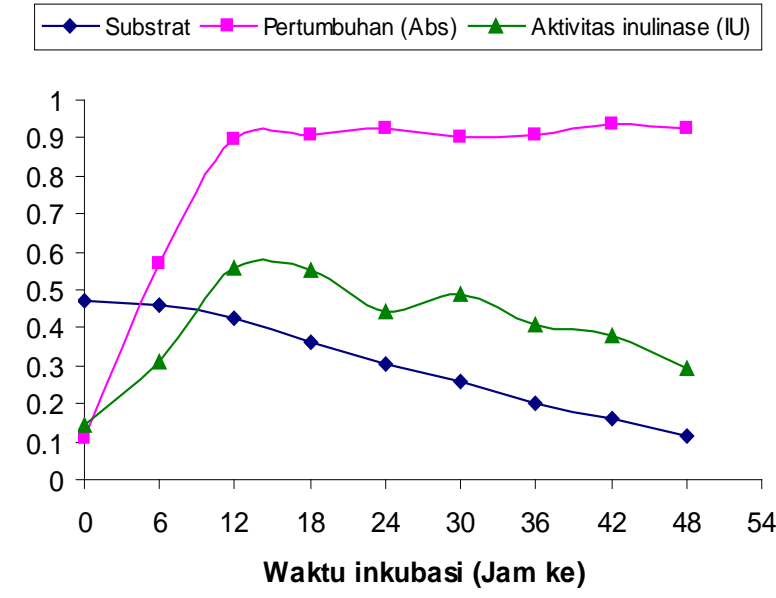

Gambar 2. Penurunan substrat dan kenaikan biomasa dan produk selama fermentasi Pichia manshurica

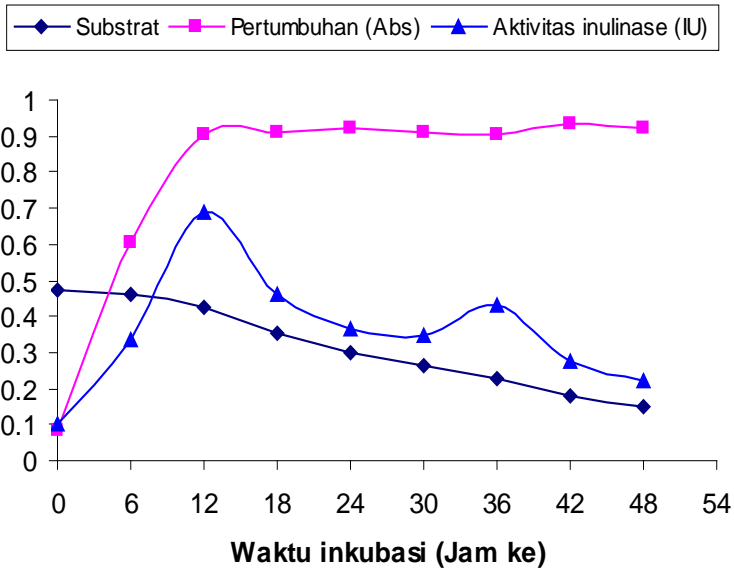

Gambar 3. Penurunan substrat dan kenaikan biomasa dan produk selama fermentasi Fusan F4.

\section{Aktivitas Enzim Inulinase}

Inulinase (E.C. 3.2.1.7.) merupakan enzim hidrolase yang mampu menghidrolisis inulin menjadi inulooligosakarida (IOS) dengan memotong satuan fruktosa dari inulin pada posisi terminal $\beta-2,1$ (Dixon dan Webb, 1979; Sing dan Gill, 2006). Jumlah inulinase yang diproduksi dapat ditentukan dengan uji aktivitas enzim (Sadikin, 2002).

Hasil penelitian menunjukkan bahwa pada jam ke-12 menghasilkan aktivitas inulinase yang tertinggi yaitu sebesar 0,69 IU untuk fusan F4 dan 0,557 IU 
untuk Pichia manshurica (Gambar 4), dengan demikian aktivitas inulinase yang dihasilkan oleh Fusan F4 lebih tinggi dari pada Pichia manshurica. Apabila dikorelasikan dengan pertumbuhan, maka produk enzim inulinase dihasilkan pada fase log dan dikatagorikan sebagai metabolisme primer. Menurut Maria dkk. (2005), aktivitas enzim yang tinggi dihasilkan pada fase log. Enzim ini digolongkan sebagai metabolit primer yang biasanya dibentuk pada fase pertumbuhan logaritmik (Brock dan Madigan, 1994). Enzim inulinase merupakan enzim yang bersifat induktif, sehingga untuk menghasilkan enzim tersebut harus di induksi dengan senyawa yang mengandung inulin (Park dkk., 2001).

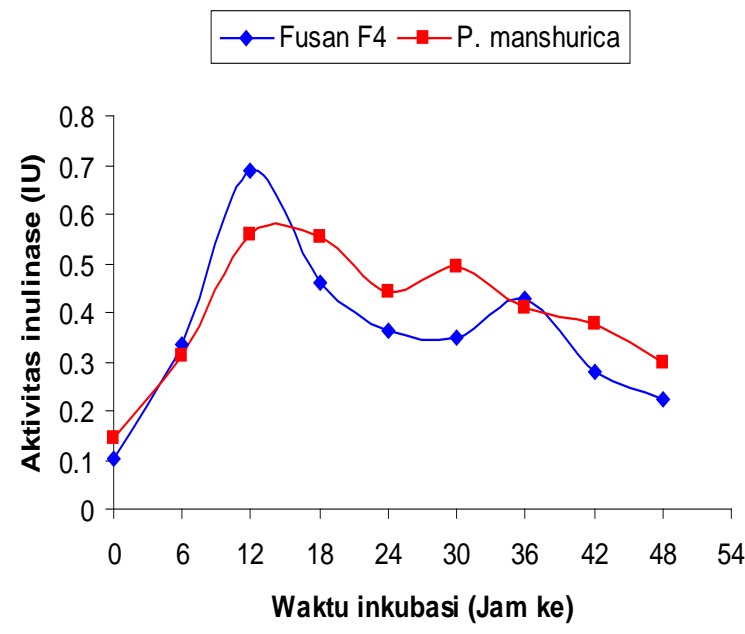

Gambar 4. Profil aktivitas inulinase (IU) Fusan F4 dan Pichia manshurica

Setelah memasuki jam ke 18 sampai jam 48, aktivitas inulinase mempunyai sifat kecenderungan untuk menurun. Hal ini disebabkan karena pada jam tersebut pertumbuhan biomasa sel telah memasuki fase stasioner (idiofase), sehingga enzim inulinase sudah tak di produksi lagi oleh sel atau sel masih memproduksi enzim tetapi jumlahnya sedikit atau menurun.

Enzim digolongkan sebagai metabolit primer yang biasanya dibentuk pada fase pertumbuhan logaritmik (eksponensial) dan tidak di produksi pada fase stasioner (Brock dan Madigan, 1994). Lebih lanjut dikatakan Madigan dkk. (2009) bahwa mekanisme pengaturan sintesis enzim di dalam sel berdasarkan pada proses induksi dan represi. Mekanisme proses induksi dan represi ini terjadi pada tahap transkripsi. Represi enzim disebabkan oleh adanya represor yaitu suatu protein khusus yang menempel pada daerah operator pada rantai DNA. Karena daerah operator telah di tempeli represor, maka RNA polimerase tidak akan menempel pada daerah operator tersebut, sebagai akibatnya maka sintesis enzim tidak akan terjadi ataupun bila ada tapi jumlahnya sangat sedikit.

\section{KESIMPULAN}

Berdasarkan penelitian tersebut diatas, maka dapat disimpulkan bahwa Fusan F4 menghasilkan aktivitas inulinase sebesar 0,69 IU, lebih tinggi dari pada Pichia manshurica 0,56 IU. Kecepatan pertumbuhan specifik $(\mu)$ untuk Fusan F4 lebih besar dari pada Pichia manshurica dengan nilai masingmasing sebesar $0,20 / \mathrm{jam}$ dan $0,18 / \mathrm{jam}$, sedangkan waktu generasi (g) sebesar 3,49 jam dan 3,90 jam. Pembentukan enzim inulinase berasosiasi dengan pertumbuhan baik untuk Fusan F4 dan Pichia manshurica.

\section{DAFTAR PUSTAKA}

Alexander, M.A. and Jeffries, T.W., (1990), Respiratory efficiency and metabolize partitioning as regulatory phenomena in yeasts, Enzyme Micobe. Technol., 12, pp. 2-29.

Allais, J.J., Kammoun, S., Blanc, P., Girard, C., and Baratti, J., (1986), Isolation and Characteristic of Bacterial Strains with Inulinase Activity, Appl. Environ. Microbiol, 52 (5), pp. 1086-1090.

Bonciu, C., Struta, V., and Bahrim, G., (2010), Isolation and Screening of New Mould Strains Able For Inulinase Biosintesis and Inulin From Jerusalem Artichoke Hydrolysis, Inovative Romanian Food Biotechnology, Vol.7, pp. 77-81.

Brock, T.D, Madigan, M.T., Martinko, J.M., and Parker, J., (1994), Biology of Microorganism, $7^{\text {th }}$ edition, Prentice-Hall International Inc. Wisconsin.

Byun, S.M. and Nahm, B.H., (1987), Production of Fructose from Jerusalem artichoke by Enzymatic Hydrolysis, J. Food Sci., 43, pp. 1871-1873.

Chaplin, M.F and Kennedy, J.F., (1994), Cahbohydrat Analysis: A Practical Approach, $2^{\text {nd }}$ Edition, Oxford University Press, Oxford.

Dinoto, A., Suksomcheep, A., Isizuka, S., Kimura, H., Hanada, S., Kamagata, Y., Asano, Tomita, F., and Yokota, A., (2006), Modulation of Rat Cecal Microbiota by Administration of Raffinose and Encapsulated, Bifidobacterium breve. App. Environ. Microbial., 72, pp. 784-792

Dixon, M. and Webb, E., (1979), Enzymes, Logman Group Ltd, London.

Ertan, F., Aktac, T., Kaboglu, A.C., Ekinci, F., and Bakar, E., (2003), Determination of Optimum Cultivation Condition on The Production of Inulinase from Rhizoctonia solani., Pak. J. Bi.l. Sci., 6 (16), pp. 1386-1388.

Lunggani, A.T, Wijanarka, dan Endang, K., (2009), Produksi IOS Prebiotik Berbasis Pemanfaatan Umbi Dahlia (Dahlia variabilis) Oleh Khamir Inulinolitik 
Dan Pengujian Antimikrobanya Secara Invitro, Penelitian Hibah Multiyears Desentralisasi.

Madigan, M., Martinko, J. M., Dunlap, P.V., and Clark, D.P., (2009), Biology of Microorganism, Twelfth edition, Pearson Benjamin Cummings, San Francisco, Booston, New York.

Mahmoud, D.A.R., El-Sayed, M.E., Mahdy. Wafaa, G.S., Hala, W.R., and Abdel Fatah, A.F., (2011), Raw Garlic as a New Substrate for Inulinase Production in Comparation to Dry Garlic, Australian Journal of Basic and Applied Sciences, 5 (10), pp. 453-462.

Mangunwidjaya dan Ani, (1994), Teknologi Bioproses, PT. Penebar Swadaya, Anggota Ikapi, Jakarta.

Maria, C. de Souza-Motta1, Maria, A. de Queiroz Cavalcanti1, Ana, L.F.P., Keila, A.M., and José L. de Lima Filho, (2005), Aspergillus niveus Blochwitz 4128URM: New Source for Inulinase Production, Journal. Brazilian Archives Biology and Technology, Vol. 48, No. 3, pp. 343-350.

Mayes, P.A., Granner, D.K., Rodwell, V.W., and Martin, D.W., (1987), Biokimia (Harper's review of Biochemistry), Terjemahan oleh Darmawan, I.C.V., EGC Penerbit, Jakarta.

Neagu, C. and Bahrim, G., (2011), Inulinases A Versatile Tool for Biotechnology, Innovative Romanian Food Biotechnology, Vol. 9, pp. 1-11.

Okpokwasili, G.C. and Nweke, C.O., (2005), Microbial Growth and Substrate Utilization Kinetics, Afr. J. Biotechnol., 5(4), pp. 305-317.

Park, J.P and Yun, J.W., (2001), Utilization of Chicory roots for Microbial Endoinulinase Production, Letters In Applied Microbiology, 2001 (33), pp. 183187.

Pessoa, A. dan Vitolo, M., (1999), Inulinase from Kluyveromyces marxianus : culture medium composition and Enzyme Extraction, Braz. Journal Chem. Eng., Vol. 16 (3), Sao Paulo.

Rukmana, R., (2000), Dahlia: Prospek Agribisnis dan Teknik Budi Daya, Penerbit Kanisius, Jogyakarta.
Rouwenhorst, R.J, Hensing, M., Verbakel, J., Scheffer, W.A., and van Dijken, J.P., (1990), Structure and Properties of the Extracellular Inulinase of Kluyveromyces marxianus CBS 6556, Appl. Environ . Microbiol., 56 (11), pp. 3337-3345.

Sadikin, M., (2002), Seri Biokimia: Biokimia Enzim, Penerbit Widya Medika, Jakarta.

Santopietro, L.M.D., Spencer, J.F.T., Spencer, D.M., and Sineriz, (1997), Characterization of intergeneric hybrids obtained by protoplast fusion between Phaffia rhodozyma, Cryptococcus laurentii and S. cerevisiae, Biotechnology technique, Vol. 11, No. 10, October 1997, pp. 769-771.

Singh, P. and Gill, P.K., (2006), Production of inulinases: Recent Advances, Food Technol. Biotechnol., 44 (2), pp. 151-162.

Songpim, M., Vaithanomst, P., Vanichsriratana, W., and Sirisansaneeyakul, S., (2011), Enhancement of Inulinase and Invertase Production from a Newly Isolated Candida guilliermondii TISTR 5844, Kasetsart J. (Nat. Sci), 45, pp. 675-685.

Tungland, B.C., (2000), Inulin A Comprehensive Scientific Review, Duncan Crow Wholistic Consultan, http://members.shaw.ca/duncancrow/inulinreview. html.

Wijanarka, Arina, E.T.L., dan Panca Sakti, H., (2005), Fusi Protoplas Interspecifik Termostabil Kluveromyces marxianus dan Torulospora pretoriensis Isolat Lokal Serta Aplikasinya Pada HFS, Prosiding Workshop/Seminar Hasil Penelitian Propinsi Jawa Tengah.

Wijanarka, Endang, K., dan Hermin, P., (2006), Paket Teknologi Eksplorasi Khamir Inulinolitik Termostabil Umbi Dahlia (Dahlia variabilis Willd.) Jawa Tengah Melalui Teknik Fusi Protoplas dan Aplikasinya pada Produksi High Fructose Syrup (HFS), Laporan Hibah Bersaing, PT XIV/1, Undip, Semarang.

Xiao, R., Tanida, M., dan Takao, S., (1988), Innulinase from Crysosporium pannorum, J. Fement. Technol., 66 (5), pp. 244-248. 